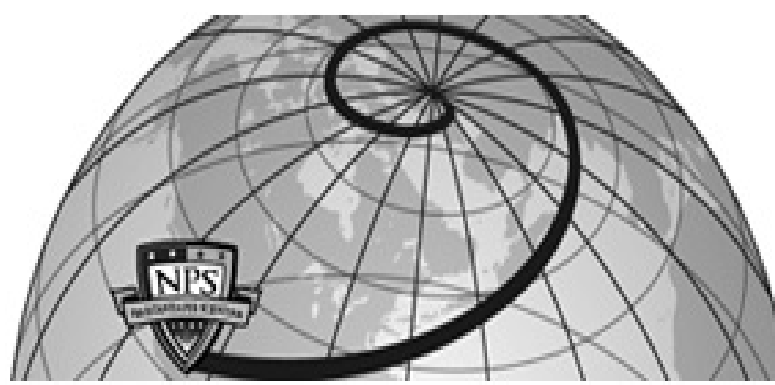

Calhoun: The NPS Institutional Archive DSpace Repository

QuikSCAT Satellite Comparisons with Nearshore Buoy Wind Data off the U.S. West Coast

Pickett, Mark H.; Tang, Wenging; Rosenfeld, Leslie K.; Wash, Carlyle $\mathrm{H}$.

Journal of Atmospheric and Oceanic Technology, Vol. 20, December 2003, pp. 1869-1879 https://hdl.handle.net/10945/46718

This publication is a work of the U.S. Government as defined in Title 17, United States Code, Section 101. Copyright protection is not available for this work in the United States.

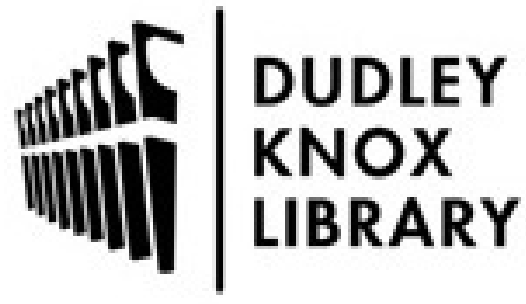

http://www.nps.edu/library
Calhoun is the Naval Postgraduate School's public access digital repository for research materials and institutional publications created by the NPS community. Calhoun is named for Professor of Mathematics Guy K. Calhoun, NPS's first appointed -- and published -- scholarly author.

Dudley Knox Library / Naval Postgraduate School 411 Dyer Road / 1 University Circle Monterey, California USA 93943 


\title{
QuikSCAT Satellite Comparisons with Nearshore Buoy Wind Data off the U.S. West Coast
}

\author{
MARK H. PicketT \\ Pacific Fisheries Environmental Laboratory, NOAA Fisheries, Pacific Grove, California \\ WENQING TANG \\ Jet Propulsion Laboratory, California Institute of Technology, Pasadena, California \\ LESLIE K. ROSENFELD \\ Department of Oceanography, Naval Postgraduate School, Monterey, California \\ Carlyle H. Wash \\ Department of Meteorology, Naval Postgraduate School, Monterey, California
}

(Manuscript received 29 July 2002, in final form 15 April 2003)

\section{ABSTRACT}

\begin{abstract}
To determine the accuracy of nearshore winds from the QuikSCAT satellite, winds from three satellite datasets (scientifically processed swath, gridded near-real-time, and gridded science datasets) were compared to those from 12 nearshore and 3 offshore U.S. West Coast buoys. Satellite observations from August 1999 to December 2000 that were within $25 \mathrm{~km}$ and $30 \mathrm{~min}$ of each buoy were used. Comparisons showed that satellite-buoy wind differences near shore were larger than those offshore. Editing the satellite data by discarding observations recorded in rain and those recorded in light winds improved the accuracy of all three datasets. After removing rain-flagged data and wind speeds less than $3 \mathrm{~m} \mathrm{~s}^{-1}$, root-mean-squared differences (satellite minus buoy) for swath data, the best of the three datasets, were $1.4 \mathrm{~m} \mathrm{~s}^{-1}$ and $37^{\circ}$ based on 5741 nearshore comparisons. By removing winds less than $6 \mathrm{~m} \mathrm{~s}^{-1}$, these differences were reduced to $1.3 \mathrm{~m} \mathrm{~s}^{-1}$ and $26^{\circ}$. At the three offshore buoys, the root-mean-squared differences for the swath data, with both rain and winds less than $6 \mathrm{~m} \mathrm{~s}^{-1}$ removed, were $1.0 \mathrm{~m} \mathrm{~s}^{-1}$ and $15^{\circ}$ based on 1920 comparisons. Although the satellite's scientifically processed swath data near shore do not match buoy observations as closely as those offshore, they are sufficiently accurate for many coastal studies.
\end{abstract}

\section{Background}

During the past 20 years numerous studies have demonstrated the ability of satellite-borne radar to measure ocean winds. This type of instrument was used on the Seasat Scatterometer System (SASS), the National Aeronautics and Space Administration (NASA) Scatterometer (NSCAT), and the European Remote Sensing satellites (ERS-1 and -2). Freilich and Dunbar (1999) assessed NSCAT's wind accuracy by comparing satellite-derived swath data to 43 buoys located off the U.S. East and West Coasts. They excluded the nearshore West Coast buoys because of low correlations but found root-

Corresponding author address: Dr. Mark H. Pickett, Pacific Fisheries Environmental Laboratory, NOAA Fisheries, 1352 Lighthouse Ave., Pacific Grove, CA 93950.

E-mail: mark.pickett@noaa.gov mean-squared (rms) wind differences offshore of $1.3 \mathrm{~m}$ $\mathrm{s}^{-1}$ and $17^{\circ}$.

The latest of the wind-measuring satellites, NASA's Quick Scatterometer (QuikSCAT), was launched into orbit on 19 June 1999 after an unexpected early termination of NSCAT. QuikSCAT is in polar orbit approximately 500 miles above the earth's surface. The satellite completes its orbit in $101 \mathrm{~min}$, and as this orbit migrates around the earth, each ocean region is overflown once every $12 \mathrm{~h}$. For the U.S. West Coast, daily overflights are within $90 \mathrm{~min}$ of 0200 and 1400 UTC. However, because of the satellite's limited viewing area and the earth's rotation, various sections of the coastal zone are only observed every few days. A rotating, dual-beam, microwave $(13.4 \mathrm{GHz})$ radar aboard the satellite measures ocean backscatter. The backscatter is then sent to ground processing stations, where a series of algorithms are used to estimate wind speed and direction at $10 \mathrm{~m}$ above the ocean surface under neutrally stable conditions 
(Liu and Tang 1996). The mission requirement was to provide winds with an rms error of $2 \mathrm{~m} \mathrm{~s}^{-1}$ and $20^{\circ}$.

The raw data from QuikSCAT are collected and managed by NASA's Jet Propulsion Laboratory (JPL). Winds from these data are provided by a number of agencies in several formats. The most commonly used datasets are near-real-time (NRT) swath data distributed by the National Oceanic and Atmospheric Administration (NOAA), scientifically processed (Level 2B) swath data distributed by NASA's Physical Oceanography Distributed Active Archive Center (PO.DAAC), and the gridded NRT and gridded science datasets distributed by the JPL. These JPL gridded datasets, as well as a few other gridded products (e.g., those produced by the Center for Ocean-Atmospheric Prediction Studies at The Florida State University, and the Remote Sensing Systems in Santa Rosa, California) are based solely on satellite data, whereas some gridded datasets use QuikSCAT data blended with other sources.

The QuikSCAT satellite is expected to remain operational and provide wind data until the summer of 2004. More information on the satellite, sensor, and data processing is available in JPL (2001), NOAA (2002), and NASA (2002).

Ebuchi et al. (2002) did an initial evaluation of the QuikSCAT swath data. They compared winds from the scientifically processed swath data to those from offshore buoys using the satellite's first year and a half of wind data. They found that when observations both in rain and light winds $\left(<5 \mathrm{~m} \mathrm{~s}^{-1}\right)$ were removed, swath data were accurate enough to meet mission requirements. After their editing, rms differences of $1.0 \mathrm{~m} \mathrm{~s}^{-1}$ and $20^{\circ}$ were obtained.

Liu et al. (2000) and Xie et al. (2001) demonstrated the value of the JPL's gridded dataset. Liu showed that this dataset was capable of depicting tropical instabilities near the equator, and Xie used the dataset to observe a wind wake trailing westward behind the Hawaiian Islands.

Because these initial studies demonstrated the satellite's value as a global oceanic wind sensor, a similar instrument was launched in December 2002 on the Japanese Advanced Earth Observation Satellite (ADEOS$I I)$. Before its launch, several studies focused on improving the data processing. Spencer et al. (2000) proposed a signal-processing technique that relied on frequency sweeping or chirping of the scatterometer to increase spatial resolution. This technique, called range slicing, can more finely segment the antenna footprint for better resolution. Portabella and Stoffelen (2001) showed that rain artificially increases satellite wind speed data and that for rain over $6 \mathrm{~mm} \mathrm{~h}^{-1}$ QuikSCAT data are unusable. Based on these findings, they proposed that a quality index be included with rain-contaminated datasets. Patoux and Brown (2001) suggested an indirect method for analyzing satellite-derived winds by first using the satellite's output to estimate the pressure field. This indirect method allowed them to correct for direction ambiguities, as well as rain and missing data.

Up until now, investigators have focused on QuikSCAT wind data over open-ocean regions where they are valuable for improving operational weather forecasting and monitoring tropical cyclones. Our interest, in contrast, is in wind data within $100 \mathrm{~km}$ of the coast. QuikSCAT offers great potential here because it samples all the world's coastal zones twice a day. Hence, we decided to investigate the accuracy of QuikSCAT's nearshore wind data.

Providing accurate nearshore wind data from satellites is challenging. First, data are unavailable very close to shore because any land within the satellite's viewing area contaminates the return signal. Second, land-sea breezes and shore topography produce small space scale and time-scale wind variations that can be smoothed by the satellite's space averaging and aliased by the satellite's twice-a-day sampling. Halliwell and Allen (1987) and Dorman and Winant (1995), for example, recorded just such wind variations using buoy data off the U.S. West Coast. Although their data showed the usual large-scale synoptic atmospheric systems, they also found nearshore wind fluctuations with spatial scales of $1-10 \mathrm{~km}$ and time scales of around 1 day. Dorman and Winant confirmed the variability of these nearshore winds by showing spectral peaks at the diurnal and semidiurnal frequencies.

The complexity of nearshore winds is one of the prime reasons that the regions are so important. For example, over one-third of the total marine fish catch occurs within this nearshore zone (FAO 1995). Strong alongshore winds drive episodes of upwelling, which in turn lead to intense biological productivity. If the QuikSCAT satellite were able to accurately measure these nearshore winds, then its data would be useful in estimating coastal upwelling. We felt that we could make reasonable estimates of upwelling with the ability to measure coastal winds greater than $4 \mathrm{~m} \mathrm{~s}^{-1}$ to within 1-2 $\mathrm{m} \mathrm{s}^{-1}$ and $30^{\circ}$. Thus, in spite of the challenge of using nearshore satellite wind data, the global coverage and the potential for estimating upwelling prompted our evaluation. We selected the U.S. West Coast for our test site because it is an active upwelling area with a large number of coastal buoys. Our intent was to answer three questions.

1) How large are the nearshore errors in three of the commonly used QuikSCAT wind data sets?

2) Can postprocessing reduce these errors?

3) Are any of these datasets accurate enough for coastal upwelling studies?

In an attempt to answer the above questions, wind data from three satellite datasets were compared to data from 12 coastal and 3 offshore buoys from August 1999 to December 2000. The locations of the buoys are shown in Fig. 1 and their properties are given in Table 1. The three satellite datasets tested were NASA's scientifically 


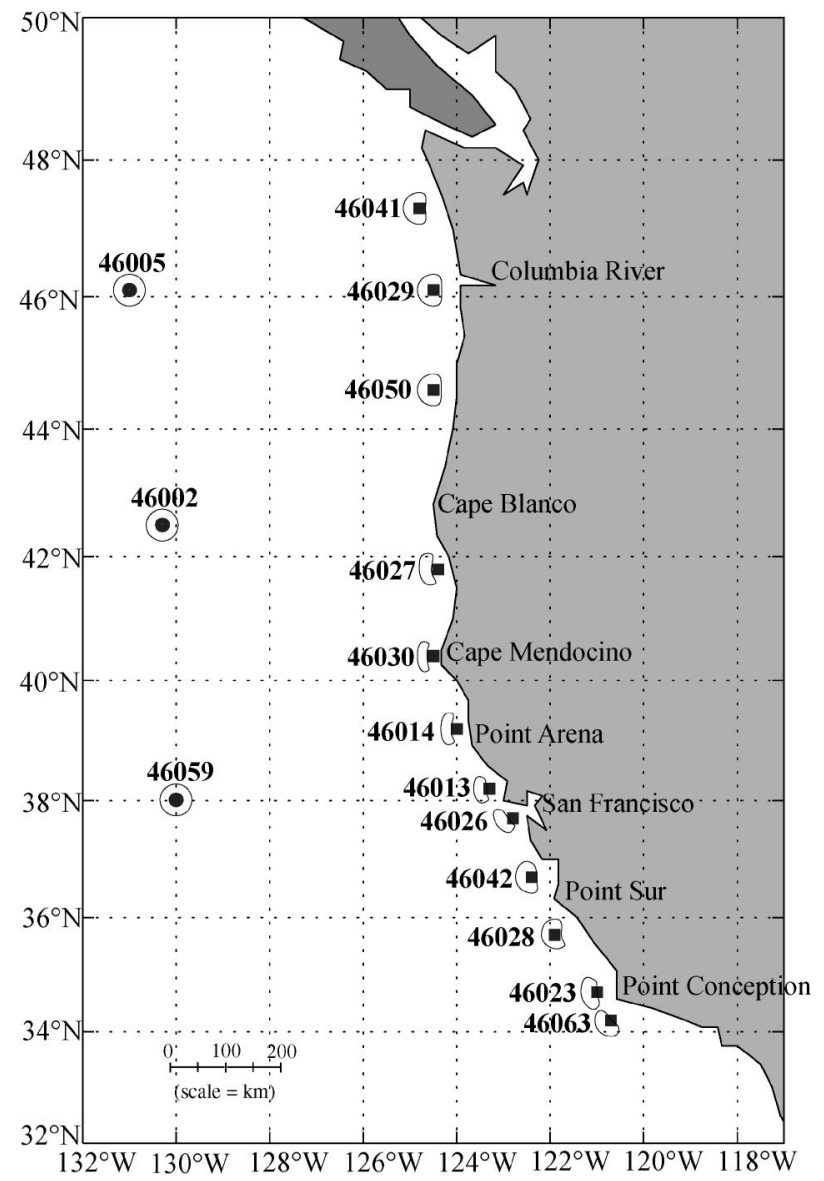

FIG. 1. Locations of 12 nearshore buoys (marked with squares) and 3 offshore buoys (circles) used to evaluate QuikSCAT satellite wind observations. Marked areas around buoys indicate the maximum allowed spatial separation of satellite and buoy observations used for comparisons.

processed swath data, JPL's gridded NRT data, and JPL's gridded science data.

\section{Data}

\section{a. Satellite}

The satellite's dual-beam radar irradiates an elliptical area $(25 \mathrm{~km}$ across the satellite's path, $37 \mathrm{~km}$ along the path) called the instantaneous field of view (IFOV). The rotating antenna and the satellite's orbit combine to move this IFOV in a cycloid that extends $900 \mathrm{~km}$ on each side of the satellite's path. As a result of this dualbeam sweeping action, QuikSCAT provides wind data over approximately $90 \%$ of the world's oceans every day. This coverage is a significant improvement over previous satellites (41\% coverage for ERS, 77\% coverage for NSCAT), but, as with all polar-orbiting satellites, observations are unevenly distributed in both time and space.

In the standard QuikSCAT data product, slices from overlapping current and previous across-track sweeps of the radar beam are then combined and averaged to provide $25 \mathrm{~km}$ by $25 \mathrm{~km}$ wind vector cells (Fig. 2). Output is not used if any part of the field of view is contaminated by land, so QuikSCAT wind data are masked, and therefore not available, within $30 \mathrm{~km}$ of the coast.

The swath dataset used in this study is referred to by NASA as QuikSCAT Level 2B. It is provided as 72 wind vector cells (WVCs) across the satellite's path, and 1624 WVCs along its path. Each WVC contains up to four possible wind vector solutions. These solutions are ranked according to a maximum-likelihood estimator based on the backscatter measurements (Long and Mendel 1991). From this ranking, a single wind vector is then selected using an ambiguity-removal algorithm. This algorithm employs a modified median filter technique (Shaffer et al. 1991) that makes a selection based on three factors: ranking from the maximum-likelihood estimator, consistency with a National Centers for Environmental Prediction (NCEP) numerical weather product, and agreement with the surrounding $(7 \times 7)$ WVCs. Near shore the relatively low resolution $\left(1^{\circ}\right.$ of latitude) of the numerical weather product and the lack of surrounding cells on the shore side of the WVC may reduce the effectiveness of the modified median filter.

Each swath WVC also has an attached rain flag. Several different techniques are available to produce these rain flags (e.g., Mears et al. 2000; Huddleston and Stiles 2000). For this study, we used the default thresholds on the standard multidimensional histogram (MUDH) rain flag described in the QuikSCAT user's manual (JPL 2001). This rain flag works by evaluating specific rainsensitive backscatter parameters to estimate rain probability in each WVC. High rain probability cells are then compared with the surrounding $(5 \times 5)$ WVCs. This is done to determine if there are a sufficient number of high probabilities among neighboring cells to warrant the rain flag.

In contrast to the unevenly distributed swath data, gridded datasets are intended to provide winds for largescale, quasi-synoptic analysis. Various techniques (Cressman 1959; Koch et al. 1983; Tang and Liu 1996; Liu et al. 1998) are employed to overcome the irregular time and space sampling of satellite wind data. These techniques are best suited for large time and space scales. The inherent time and space aliasing is usually dealt with by averaging. For example, Schlax et al. (2001) demonstrated that sampling errors on the order of $1 \mathrm{~m} \mathrm{~s}^{-1}$ occur when synoptic wind fields are created from irregularly spaced QuikSCAT swath data. To minimize this error, they had to average the swath data over $1^{\circ}$ and 2 days. Hence, gridded datasets are generally designed to trade off point-to-point accuracy in order to preserve and display the large-scale properties of the wind field.

The gridded NRT data we used are produced by an objective analysis of a special quickly generated set of swath data. To be useful in operational weather fore- 
TABLE 1. Properties of the dataset used to compare QuikSCAT swath and buoy wind data. Separation distances are the average distance between the center of the satellite's wind observation area and the buoy's location.

\begin{tabular}{|c|c|c|c|c|c|}
\hline & Position (lat, lon) & $\begin{array}{l}\text { Distance from shore } \\
\qquad(\mathrm{km})\end{array}$ & No. of matching pairs & $\begin{array}{l}\text { Average separation } \\
\text { distance }(\mathrm{km})\end{array}$ & $\begin{array}{l}\text { Correlation } \\
\text { (speed) }\end{array}$ \\
\hline \multicolumn{6}{|l|}{ Nearshore buoys } \\
\hline Buoy 46041 & $47.3^{\circ} \mathrm{N}, 124.8^{\circ} \mathrm{W}$ & 34 & 554 & 9 & 0.9 \\
\hline Buoy 46029 & $46.1^{\circ} \mathrm{N}, 124.5^{\circ} \mathrm{W}$ & 36 & 486 & 9 & 0.9 \\
\hline Buoy 46050 & $44.6^{\circ} \mathrm{N}, 124.5^{\circ} \mathrm{W}$ & 35 & 563 & 10 & 0.9 \\
\hline Buoy 46027 & $41.8^{\circ} \mathrm{N}, 124.4^{\circ} \mathrm{W}$ & 13 & 198 & 22 & 0.8 \\
\hline Buoy 46030 & $40.4^{\circ} \mathrm{N}, 124.5^{\circ} \mathrm{W}$ & 8 & 252 & 22 & 0.9 \\
\hline Buoy 46014 & $39.2^{\circ} \mathrm{N}, 124.0^{\circ} \mathrm{W}$ & 17 & 485 & 17 & 0.8 \\
\hline Buoy 46013 & $38.2^{\circ} \mathrm{N}, 123.3^{\circ} \mathrm{W}$ & 22 & 591 & 14 & 0.9 \\
\hline Buoy 46026 & $37.7^{\circ} \mathrm{N}, 122.8^{\circ} \mathrm{W}$ & 20 & 496 & 17 & 0.8 \\
\hline Buoy 46042 & $36.7^{\circ} \mathrm{N}, 122.4^{\circ} \mathrm{W}$ & 35 & 562 & 9 & 0.9 \\
\hline Buoy 46028 & $35.7^{\circ} \mathrm{N}, 121.9^{\circ} \mathrm{W}$ & 41 & 354 & 10 & 0.9 \\
\hline Buoy 46023 & $34.7^{\circ} \mathrm{N}, 121.0^{\circ} \mathrm{W}$ & 31 & 628 & 9 & 0.9 \\
\hline \multirow[t]{2}{*}{ Buoy 46063} & $34.2^{\circ} \mathrm{N}, 120.7^{\circ} \mathrm{W}$ & 30 & 572 & 13 & 0.9 \\
\hline & & Mean $=27 \mathrm{~km}$ & Total obs $=5741$ & Mean $=13 \mathrm{~km}$ & \\
\hline \multicolumn{6}{|l|}{ Offshore buoys } \\
\hline Buoy 46005 & $46.1^{\circ} \mathrm{N}, 131.0^{\circ} \mathrm{W}$ & 545 & 704 & 10 & 0.9 \\
\hline Buoy 46002 & $42.5^{\circ} \mathrm{N}, 130.3^{\circ} \mathrm{W}$ & 475 & 420 & 10 & 0.9 \\
\hline \multirow[t]{2}{*}{ Buoy 46059} & $38.0^{\circ} \mathrm{N}, 130.0^{\circ} \mathrm{W}$ & 540 & 796 & 10 & 0.9 \\
\hline & & Mean $=520 \mathrm{~km}$ & Total obs $=1920$ & Mean $=10 \mathrm{~km}$ & \\
\hline
\end{tabular}

casting, data must be available within $3 \mathrm{~h}$ after the satellite passes any location. To meet this need, a nearreal-time swath dataset is generated. For the sake of speed, this dataset is produced from backscatter measurements with minimal time devoted to geophysical processing. Winds are retrieved using the same algorithm as the Level 2B swath data but employ only averaged backscatter measurements instead of the more sophisticated slice composites. Also, a numerical weather forecast product is used to prime the ambiguity-re-

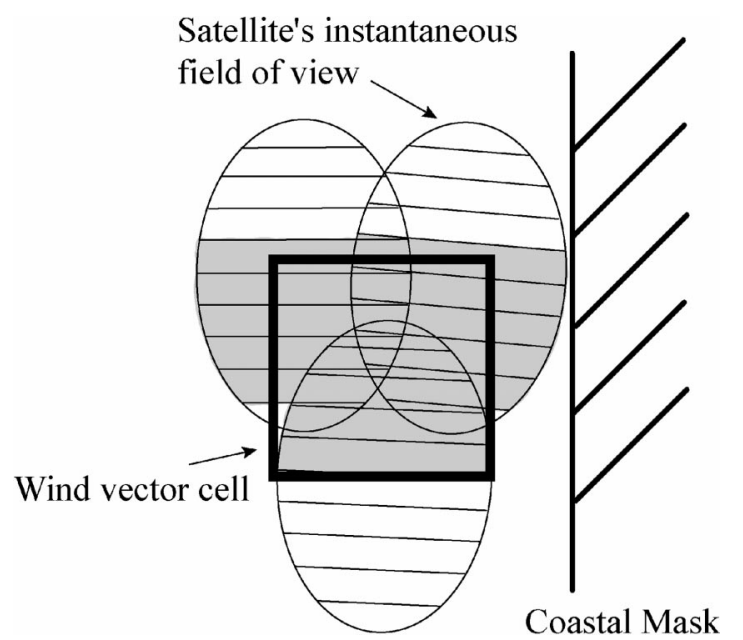

FIG. 2. Simplified schematic showing backscatter measurements from the QuikSCAT satellite. As the satellite's field of view (elliptical area) sweeps across the satellite's path, current and previous fields of view overlap. These fields are divided into slices, which are then combined to create $25-\mathrm{km}$ wind vector cells. If any part of the field of view is determined to be within the coastal mask, the entire wind vector cell is flagged as contaminated. moval algorithm. To create the final gridded dataset, a successive correction technique is used to interpolate the swath data onto a $0.5^{\circ}$ grid once every $12 \mathrm{~h}$.

The gridded science dataset is produced using the same objective analysis technique as above (Tang and Liu 1996), except the input data are from the more highly processed Level 2B swath data. More sophisticated space, time, and ambiguity algorithms are used, and rain-contaminated cells are removed.

\section{b. Buoys}

The 12 nearshore buoys used in our comparisons ranged from 8 to $41 \mathrm{~km}$ off the U.S. West Coast and were separated by $100-200 \mathrm{~km}$ north-south. The three offshore buoys were approximately $500 \mathrm{~km}$ offshore and separated by about $400 \mathrm{~km}$ north-south. Most buoys had anemometers $5 \mathrm{~m}$ above the sea surface, but one (46023) had a 10-m anemometer. The buoys transmit wind speed and direction each hour based on an 8-min scalar average from minute 42 to minute 50 . Tests by Hamilton (1980) and Gilhousen (1987) showed that the buoys have rms wind errors of $1.0 \mathrm{~m} \mathrm{~s}^{-1}$ and $10^{\circ}$.

\section{c. Matching observations}

Using the times and positions contained in the swath data, our first task was to select a single satellite observation matching each buoy observation. Since the area observed by the satellite is constantly moving, time and space tolerance intervals were necessary in order to gather reasonable numbers of comparisons. Any interval, however, potentially introduces errors, especially in variable nearshore winds, because the satellite and 
buoy will not be recording at exactly the same time and place. These interval-related errors only arise in comparison studies, however, since satellite-derived wind observations are normally used when and where they are measured.

Many different tolerance intervals have been tried in satellite-buoy comparison studies [Ebuchi et al. (2002), 25 km-30 min; Freilich and Dunbar (1999), 50 km-30 min; Atlas et al. (1999), 100 km-90 min]. Since 12 of the buoys we used were within the variable nearshore wind field, we selected a $25-\mathrm{km}$ space tolerance that allowed reasonable numbers of satellite-buoy matches. Since the nearshore buoys were located at the very edge of the satellite's land-contaminated view, we ended up with the offshore-skewed tolerance intervals shown in Fig. 1.

The time tolerance interval for the comparisons was determined by how closely the twice-daily satellite overflights matched the hourly buoy readings. The satellitebuoy mean time separation was only $16 \mathrm{~min}$ for the swath data at all 15 buoys. The correlation coefficients shown in Table 1 show a high level of agreement between the satellite and buoy wind speed measurements using the above time and space intervals.

Both gridded datasets were already provided on a $0.5^{\circ}$ grid at 0000 and 1200 UTC. Our comparisons for the gridded datasets were done by simply selecting a wind value at the closest grid point to each buoy for both of the gridded satellite datasets. Hence, the space interval was always less than $30 \mathrm{~km}$.

To match the analysis time for the gridded datasets, we decided to vector average the buoy wind values over 4-h intervals centered on 0000 and 1200 UTC. A 4-h average was used in an attempt to match the smoothing applied by the objective analysis used to produce the gridded data. The satellite observations that contribute the most to the objective analysis are typically within $2 \mathrm{~h}$ of verification time off the U.S. West Coast.

\section{d. Corrections}

For all three datasets, two wind speed corrections were considered. The first was for stability. Satellite wind data are based on neutral stability, whereas buoys measure winds in whatever stability exists locally. Mears et al.'s (2001) 11-yr study at 60 buoy locations found that stability differences introduce wind speed errors of only about $0.1 \mathrm{~m} \mathrm{~s}^{-1}$. Also, their range of stability conditions covered the entire range we encountered. Because the expected errors associated with stability differences were a small percentage of the minimal wind speed used in this study $\left(3 \mathrm{~m} \mathrm{~s}^{-1}\right)$, we neglected stability errors.

The second correction was for anemometer height. The satellite is purported to provide wind observations at $10 \mathrm{~m}$ above the ocean surface, whereas most of the buoys we used measured winds at $5 \mathrm{~m}$. To adjust the buoy-derived wind to $10 \mathrm{~m}$, we followed Smith's (1988) method. The corrections amounted to about a $7 \%$ increase in all buoy wind speeds measured at 5-m heights.

After the corrections were applied, buoy-derived wind speed and direction were subtracted from the closest matching satellite-derived wind speed and direction. This was repeated for all three satellite datasets. A1though the satellite flew over the U.S. West Coast twice a day during our year-and-a-half observation period, each pass did not cover every buoy location. Hence, we were only able to obtain several hundred comparisons within our space and time tolerances at each buoy location. Comparisons at the 12 nearshore buoys were then combined to estimate overall satellite-buoy agreement for the entire coastal zone for all seasons. The three offshore buoys were combined in similar fashion to provide a reference for comparison with the nearshore data.

\section{e. Swath data tests}

The first tests were done on the swath data. Since the satellite's operational range is $3-30 \mathrm{~m} \mathrm{~s}^{-1}$, all data where buoys recorded winds less than $3 \mathrm{~m} \mathrm{~s}^{-1}$ were discarded. Next, rain-flagged data were removed. When overall satellite-buoy differences with and without rain were compared, there was very little difference because so little rain occurred during the test period.

After rain removal, we then studied the effects of light winds on swath data. Freilich and Dunbar (1999) showed that NSCAT satellite data contained random component errors that resulted in large direction errors at low wind speeds. They also showed that these large direction errors were greatly reduced at wind speeds greater than $6 \mathrm{~m} \mathrm{~s}^{-1}$. Following their lead, we removed all observations where buoys recorded wind speeds less than $6 \mathrm{~m} \mathrm{~s}^{-1}$. This editing produced a major reduction in satellite-buoy direction differences but no reduction in speed differences.

\section{f. Gridded data tests}

The next comparisons were with the two gridded datasets. These datasets use swath data as their source but are produced only after the swath data have undergone extensive objective analysis and smoothing. The results are provided on a $0.5^{\circ}$ grid at 0000 and 1200 UTC. There are two main differences between these two gridded datasets. The gridded NRT data has rain left in, and it uses the less sophisticated NRT swath data processing scheme.

To obtain comparable wind observations, we smoothed the buoy winds by using 4-h vector averages. These averages were centered on 0000 and 1200 UTC to match the gridded dataset times. Next, each buoy wind average was subtracted from the wind value at the closest grid point in the gridded dataset. Finally, we combined all the nearshore differences over the entire observation period for the 12 coastal buoys and did the 

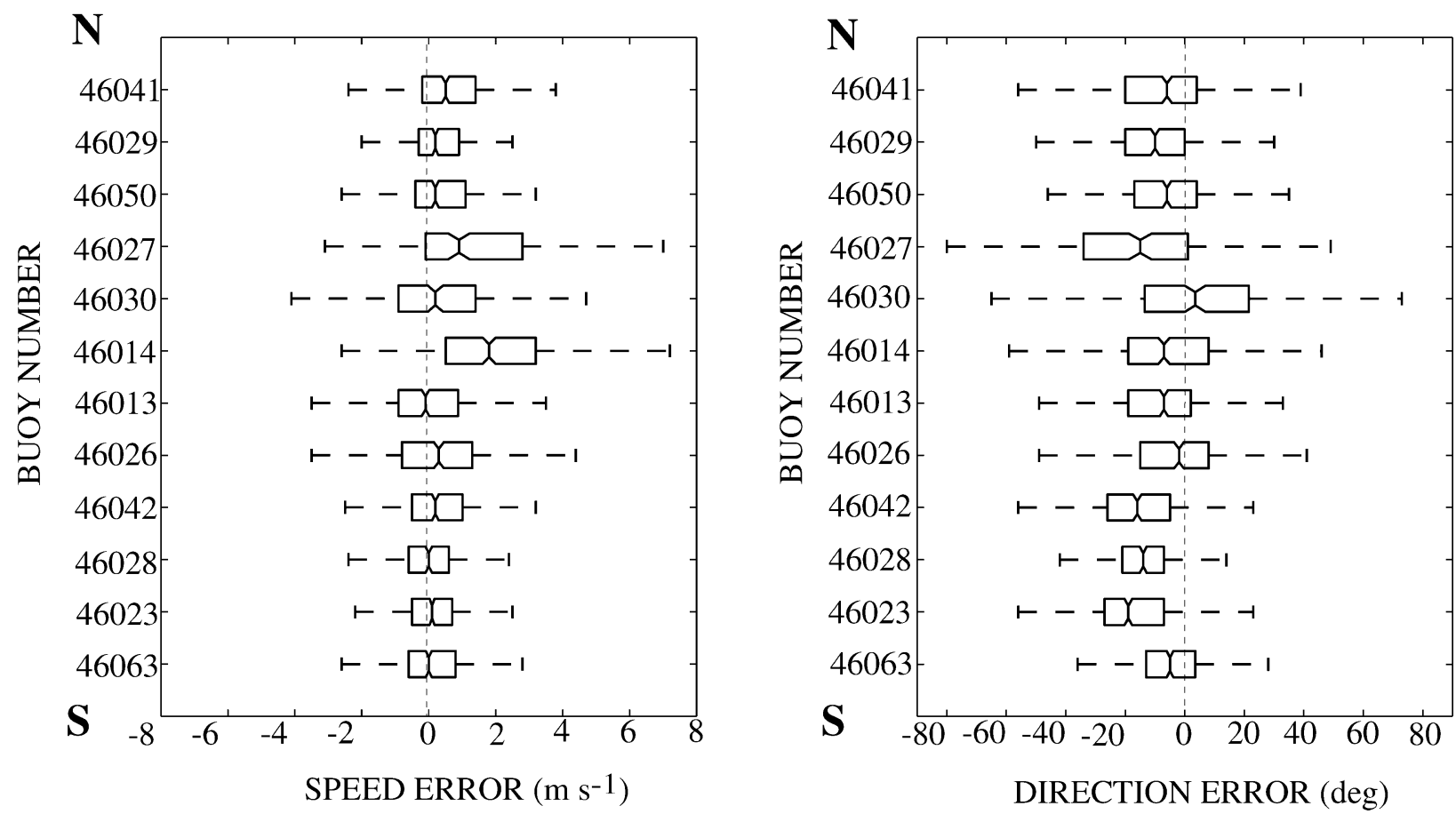

FIG. 3. Distributions of differences between QuikSCAT swath and nearshore buoy wind data for all 12 nearshore buoys: (left) speed differences and (right) direction differences. Each box shows the 25th, 50th, and 75th distribution percentiles. Dotted lines show the rest of the distribution, excluding outlying points (greater than 1.5 times the interquartile range). Notches in boxes represent confidence intervals about the 50th percentile.

same for the 3 offshore buoys. This entire process was repeated for both the gridded NRT and the gridded science datasets.

\section{Results}

\section{a. Nearshore swath data}

Figure 3 shows box plots of satellite-buoy wind differences for the swath data at each nearshore buoy. There are considerable buoy-to-buoy differences. The mean speed difference varied from 0.0 to $2.0 \mathrm{~m} \mathrm{~s}^{-1}$, and the mean direction difference varied from $1^{\circ}$ counterclockwise to $17^{\circ}$ clockwise. Our calculations showed that these buoy-to-buoy variations were not significantly correlated with latitude, longitude, coastal topography, distance from shore, or satellite-buoy separation distance.

The combined swath data differences for all 12 nearshore buoy locations are shown in Fig. 4. The distribution of speed differences is fairly normal, but the direction distribution is not normal because of some very large errors. The mean speed difference is $0.5 \mathrm{~m}$ $\mathrm{s}^{-1}$, and the mean direction difference is $9^{\circ}$ clockwise. In order to calculate the combined rms value for all 12 buoys, we employed a pooled variance technique. This technique is used when data samples have similar variances but dissimilar means (Dixon and Massey 1969). Using this technique, the combined nearshore rms speed value was $1.6 \mathrm{~m} \mathrm{~s}^{-1}$, and the rms direction value was $38^{\circ}$.

Removing rain from the swath data had little overall effect because less than $10 \%$ of satellite-derived winds had rain flags during our test period. The rms values only decreased from 1.6 to $1.4 \mathrm{~m} \mathrm{~s}^{-1}$ and from $38^{\circ}$ to $37^{\circ}$. Nevertheless, removing rain eliminated some instances in which the satellite had much higher wind speed values than those the buoy recorded, so it is an important editing tool.

In contrast to the minor effect of discarding rainflagged observations, removing buoy wind speed values between 3 and $6 \mathrm{~m} \mathrm{~s}^{-1}$ had a major effect, by eliminating most large direction differences. Figure 5 shows error histograms for swath data with both rain and winds less than $6 \mathrm{~m} \mathrm{~s}^{-1}$ removed. Speed differences have not changed much, but direction differences are both smaller and closer to a normal distribution. The rms values at all 12 nearshore buoys with both rain and winds less than $6 \mathrm{~m} \mathrm{~s}^{-1}$ removed dropped from the unedited values of $1.6 \mathrm{~m} \mathrm{~s}^{-1}$ and $38^{\circ}$ down to $1.3 \mathrm{~m} \mathrm{~s}^{-1}$ and $26^{\circ}$.

\section{b. Nearshore gridded data}

The gridded near-real-time dataset initially incorporates all satellite data into the analysis, including observations in light winds and rain. These error-prone measurements could not be removed from our compar- 


\section{All Nearshore Comparisons}
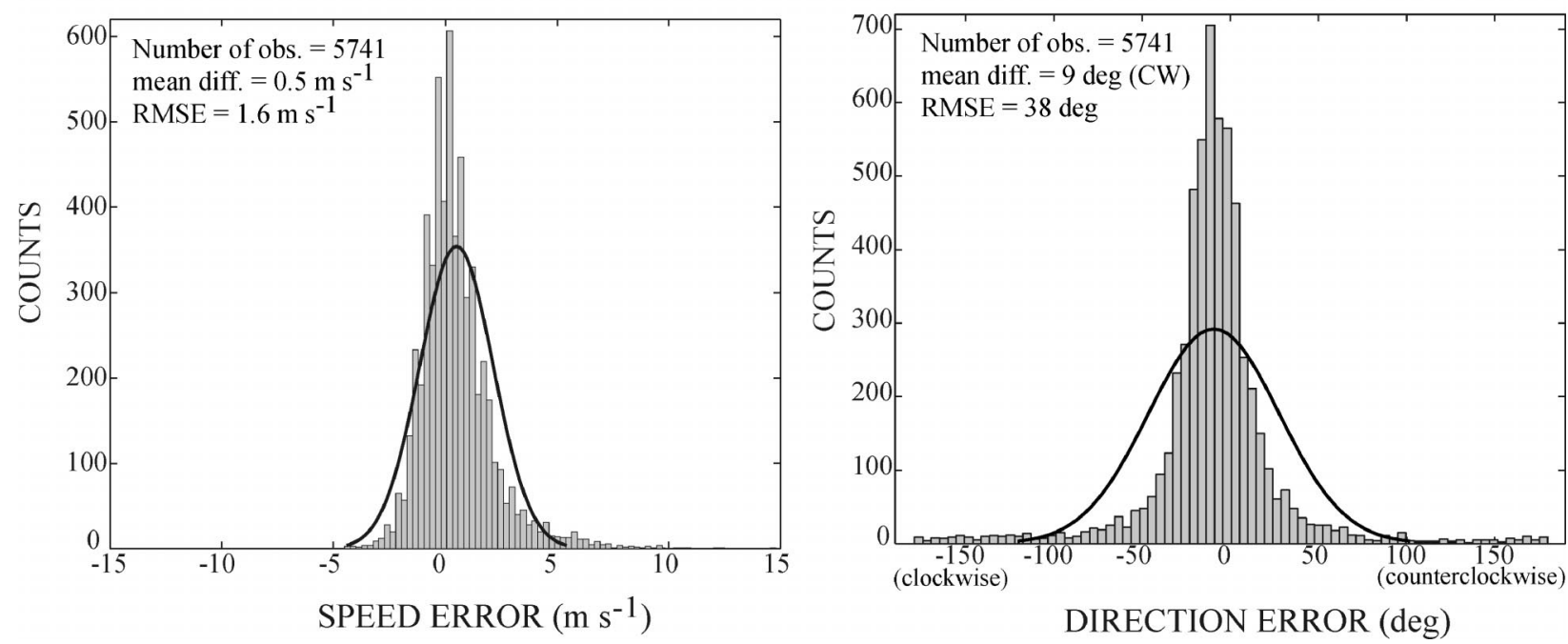

FIG. 4. Cumulative histograms of wind differences between QuikSCAT swath data and nearshore buoys for all 12 nearshore buoys: (left) speed differences and (right) direction differences. Solid curves are normal distributions. Winds less than $3 \mathrm{~m} \mathrm{~s}^{-1}$ have been removed; rain has not. Speed differences are approximately normally distributed but have a grouping of large errors on the right-hand side of the histogram. Direction differences, however, are not normally distributed because of the large errors on both sides of the histogram.

isons, because they have already been smoothed into surrounding points through the objective analysis scheme. Nevertheless, we attempted to partially discard light winds by removing all comparisons that had 4-haveraged buoy wind speeds less than $6 \mathrm{~m} \mathrm{~s}^{-1}$. The rms differences after this editing were $3.2 \mathrm{~m} \mathrm{~s}^{-1}$ and $45^{\circ}$, which are considerably larger than the swath comparisons.

The gridded science dataset has rain removed before analysis and uses a more sophisticated ambiguity-removal algorithm, so theoretically it should better match the buoys than the gridded NRT data. Once again, we removed all comparisons where the buoy $4-\mathrm{h}$ wind speed average was less than $6 \mathrm{~m} \mathrm{~s}^{-1}$. The results indicated that large direction differences, especially in the clockwise direction, were still a major source of error. These large differences are most likely due to bad directions recorded in light winds that have been incorporated into

\section{Nearshore with Rain and Light Winds Removed}
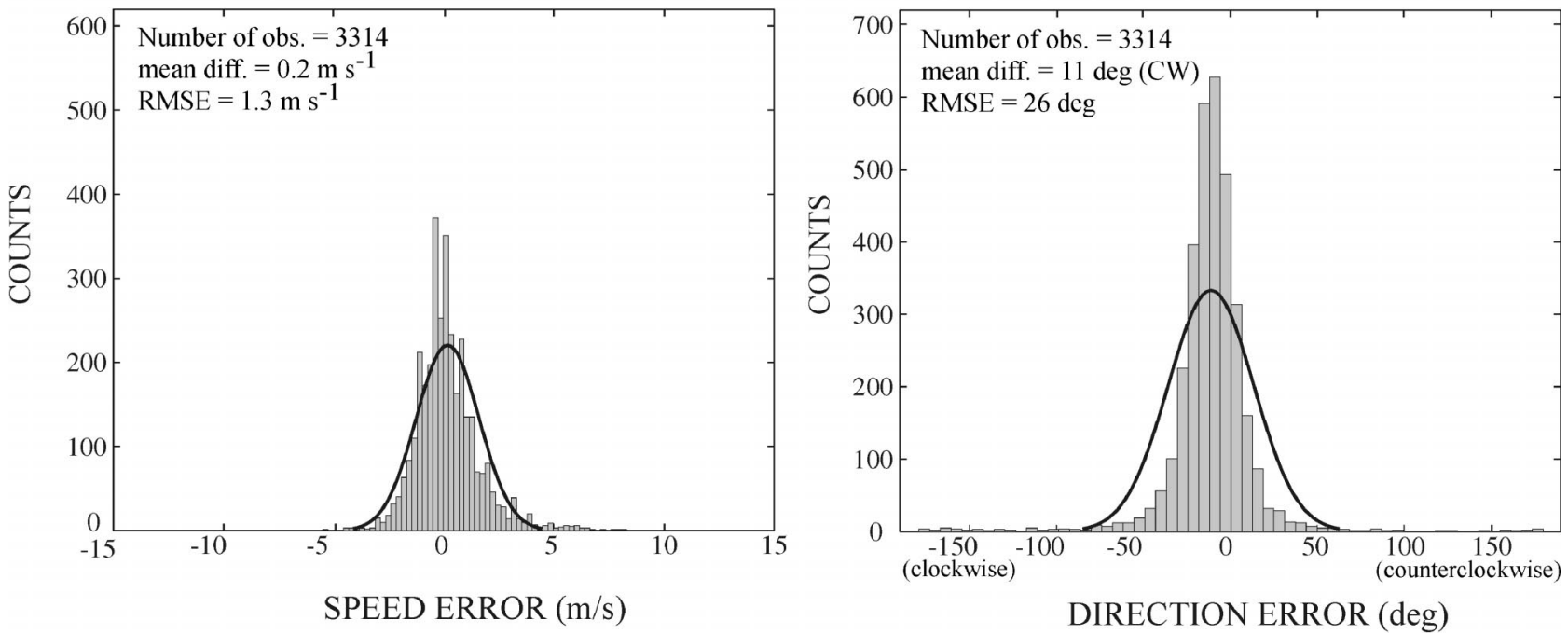

FIG. 5. Cumulative histograms of edited wind differences between QuikSCAT swath data and nearshore buoys, with rain-flagged observations and winds less than $6 \mathrm{~m} \mathrm{~s}^{-1}$ removed. Both speed and direction differences are more normally distributed. 


\section{Offshore with Rain and Light Winds Removed}
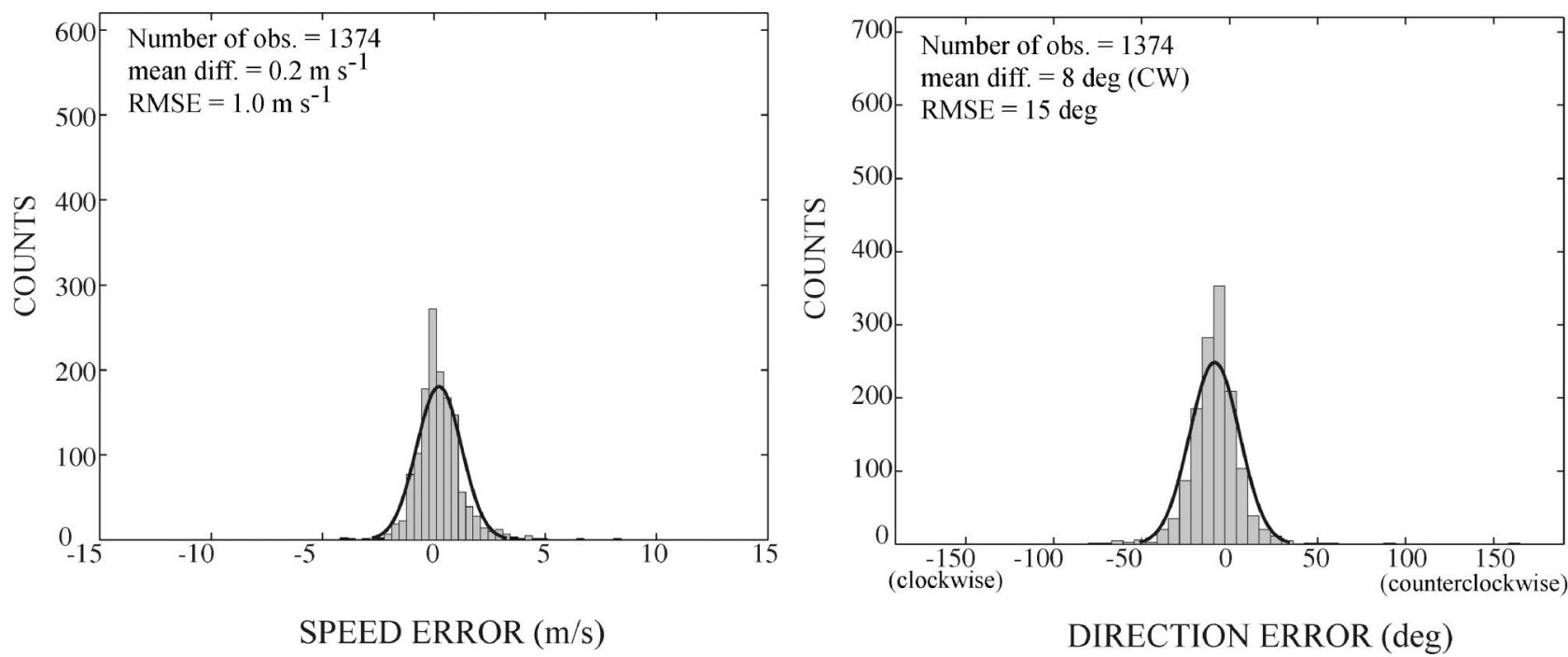

FIG. 6. Cumulative histograms of edited wind differences between QuikSCAT swath data and offshore buoys, with rain-flagged observations and winds less than $6 \mathrm{~m} \mathrm{~s}^{-1}$ removed. Both wind speed and direction differences are approximately normally distributed

the analysis. The rms differences for the gridded science dataset were $3.1 \mathrm{~m} \mathrm{~s}^{-1}$ and $41^{\circ}$, only slightly smaller than the gridded NRT dataset. Apparently, improvements in gridded science data due to rain removal, and to the more sophisticated swath processing, are overwhelmed by the effects of the objective analysis on observations scattered in both space and time.

\section{c. Offshore comparisons}

We also combined satellite-buoy differences at the three offshore buoys. With rain and winds less than 6 $\mathrm{m} \mathrm{s}^{-1}$ removed, offshore swath data differences, shown in Fig. 6, were more normally distributed and had considerably smaller rms values than those near shore. The overall mean speed difference was $0.2 \mathrm{~m} \mathrm{~s}^{-1}$, and the mean direction difference was $8^{\circ}$ clockwise. The rms values dropped from $1.3 \mathrm{~m} \mathrm{~s}^{-1}$ and $26^{\circ}$ near shore to $1.0 \mathrm{~m} \mathrm{~s}^{-1}$ and $15^{\circ}$ offshore. These values are similar to offshore buoy comparisons from QuikSCAT done by Ebuchi et al. (2002, $1.0 \mathrm{~m} \mathrm{~s}^{-1}$ and $\left.20^{\circ}\right)$ and from NSCAT done by Freilich and Dunbar (1999, $1.3 \mathrm{~m} \mathrm{~s}^{-1}$ and $\left.17^{\circ}\right)$.

Both gridded datasets also have lower errors offshore than near shore. The offshore rms values for the NRT gridded data dropped from $3.2 \mathrm{~m} \mathrm{~s}^{-1}$ and $45^{\circ}$ to $2.7 \mathrm{~m}$ $\mathrm{s}^{-1}$ and $42^{\circ}$. The differences in the gridded science data went from $3.1 \mathrm{~m} \mathrm{~s}^{-1}$ and $41^{\circ}$ to $2.5 \mathrm{~m} \mathrm{~s}^{-1}$ and $41^{\circ}$.

We initially assumed that the higher swath data differences near shore resulted mainly from the seaward bias of the satellite-buoy comparison areas (shown in Fig. 2). These skewed areas resulted in somewhat larger satellite-buoy separation near shore (13-km mean near shore, $10-\mathrm{km}$ mean offshore). Since many investigators (Bakun and Nelson 1991; Beardsley et al. 1987; Huyer and Kosro 1987) have shown wind speeds increasing with distance from shore, we expected this bias might account for much of the difference between offshore and nearshore comparisons.

Our attempt to verify the above effect was unsuccessful, however. Regression analyses of wind speed difference versus separation distance at each of the 12 nearshore buoys showed no consistent increase of wind speed difference with increasing satellite-buoy separation. At some locations, satellite and buoy wind speed data actually matched better with increasing separation. This regression analysis led us to conclude that satellitebuoy separation could not account for all of our observed nearshore-to-offshore differences.

Our next attempt to explain the difference between offshore and nearshore comparisons involved examining the wind's spectral characteristics using hourly buoy wind data. We found that the winds at the 12 nearshore buoys had large amounts of diurnal energy, as well as other high frequencies, compared to those offshore. We also found that the strength of nearshore diurnal energy varied significantly from buoy to buoy, even at locations within $100 \mathrm{~km}$ of each other. Because, in general, highfrequency atmospheric phenomena have smaller spatial scales, the increased high-frequency energy we found at the nearshore locations in conjunction with the satellite's spatial averaging may have resulted in the larger nearshore satellite-buoy differences.

\section{d. Confidence limits}

We used standard-error calculations (Dixon and Massey 1969) to estimate confidence limits for satellitebuoy differences. These calculations use the time and 
TABLE 2. Summary of differences between QuikSCAT satellite swath data and buoy wind data.

\begin{tabular}{|c|c|c|c|c|c|c|}
\hline \multirow{3}{*}{$\begin{array}{l}\text { QuikSCAT } \\
\text { data }\end{array}$} & \multirow[b]{3}{*}{ Editing } & \multirow{3}{*}{$\begin{array}{c}\text { No. of } \\
\text { observations }\end{array}$} & \multicolumn{2}{|c|}{ Mean error } & \multirow{2}{*}{\multicolumn{2}{|c|}{ Rms error }} \\
\hline & & & & Direction & & \\
\hline & & & Speed $\left(\mathrm{m} \mathrm{s}^{-1}\right)$ & ( ${ }^{\circ}$ clockwise $)$ & Speed $\left(\mathrm{m} \mathrm{s}^{-1}\right)$ & Direction $\left({ }^{\circ}\right)$ \\
\hline \multicolumn{7}{|l|}{ Nearshore } \\
\hline Swath & Rain in, winds $<3 \mathrm{~m} \mathrm{~s}^{-1}$ out & 5741 & $0.5( \pm 0.1)$ & $9( \pm 2)$ & $1.6( \pm 0.1)$ & $38( \pm 3)$ \\
\hline Swath & Rain out, winds $<3 \mathrm{~m} \mathrm{~s}^{-1}$ out & 5241 & $0.4( \pm 0.1)$ & $9( \pm 2)$ & $1.4( \pm 0.1)$ & $37( \pm 3)$ \\
\hline Swath & Rain out, winds $<6 \mathrm{~m} \mathrm{~s}^{-1}$ out & 3314 & $0.2( \pm 0.1)$ & $11( \pm 2)$ & $1.3( \pm 0.1)$ & $26( \pm 2)$ \\
\hline \multicolumn{7}{|l|}{ Offshore } \\
\hline Swath & Rain out, winds $<3 \mathrm{~m} \mathrm{~s}^{-1}$ out & 1895 & $0.2( \pm 0.1)$ & $8( \pm 1)$ & $1.0( \pm 0.1)$ & $20( \pm 1)$ \\
\hline Swath & Rain out, winds $<6 \mathrm{~m} \mathrm{~s}^{-1}$ out & 1374 & $0.2( \pm 0.1)$ & $8( \pm 1)$ & $1.0( \pm 0.1)$ & $15( \pm 1)$ \\
\hline
\end{tabular}

space wind-correlation scales to estimate degrees of freedom. The effect is equivalent to reducing the number of observations used for calculating confidence limits. For the U.S. West Coast, these scales are typically a few days and several hundred kilometers (Halliwell and Allen 1987).

In our case, however, we were not dealing with wind observations directly but rather with wind differences measured by two independent systems. Based on autocorrelations of the satellite-buoy differences, we found wind-difference correlation time scales to be less than a day and alongshore space scales to be between 100 and $300 \mathrm{~km}$. Using these values, we ended up with 1663 degrees of freedom for the 5741 swath observations. Table 2 is a summary of all statistics, including confidence limits, for the nearshore and offshore swath data.

\section{Discussion}

Based on our comparisons of three QuikSCAT datasets (swath, gridded near-real-time, and gridded science datasets), swath data provide the best agreement with nearshore buoy wind data. This was as expected since gridded datasets are not designed to provide pointto-point accuracy but rather to depict large-scale wind patterns. All three datasets, however, contain two types of errors near shore.

The first type consisted of large wind direction errors. In addition to the numerous direction errors recorded by the satellite in light winds, we occasionally found large errors at higher wind speeds. These errant wind directions typically occurred for a single satellite observation, and with a frequency of about 1 observation in 50. Although these direction errors were usually possible to identify in our large statistical samples, they would not be easy to discern in operational applications. We suspect that these large direction errors are due to improper ambiguity removal in the satellite data processing scheme. Near shore, the effectiveness of the ambiguity-removal process is limited by two factors: first, the numerical weather product used in the nudging process has just a $1^{\circ}$ of latitude resolution in complex nearshore winds; and second, the modified median filter is hampered by the lack of wind vector cells on the shore side.
Other wind direction ambiguity-removal algorithms are available. For example, the Direction Interval Retrieval with Threshold Nudging (DIRTH) algorithms make greater use of spatial information in determining the wind vector but, as a result, are more likely to smooth small-scale nearshore features (Stiles et al. 2002).

As a result of the above difficulties in the currently available direction algorithms, the best procedure at present for improving QuikSCAT nearshore wind direction measurements seems to be editing. Removing light winds greatly reduces the number of large direction errors. Also, time series plots of wind direction could be used to highlight single-point spikes that may be reduced or removed using techniques such as averaging or bandpass filtering. Such editing can also be used to remove direction biases such as the clockwise offset we found at 11 of the 12 nearshore buoys and all offshore buoys.

The second type of error consisted of large wind speed spikes. QuikSCAT wind speeds are known to be erratic in rain, but even after we removed rain-flagged cells, some large single-point wind speed errors remained. We discovered that by decreasing the thresholds in the rain-flagging algorithm, most of these large errors could be removed. Unfortunately, this technique also removed some surrounding good data as well. Apparently the satellite's rain flag is somewhat less effective near shore, where the algorithm is hampered by the lack of comparison cells on the shore side.

These large speed errors were few in number in our study because there was little rain in the area during our test period. In nearshore regions with moderate to heavy rain, however, either a more effective rain flag, or a wind-retrieval algorithm capable of making wind estimates in rain, is necessary.

Even after our low wind speed and rain editing of the swath data, there were still large differences between offshore and nearshore satellite-buoy comparisons. At nearshore buoys, satellite-buoy speed differences were about $30 \%$ larger, and direction differences were about $70 \%$ larger than at offshore buoys. Since the gridded datasets are derived from swath data, they showed the same pattern of differences. Our conclusion is that these 
differences were mainly due to the complexity of the coastal winds. Spectral analysis showed that winds at the nearshore buoys had more high-frequency energy, and more buoy-to-buoy variability, than those at the offshore buoys. Others have observed this as well. For example, Beardsley et al. (1987) and Winant et al. (1987) measured nearly a threefold increase in wind speed and a $30^{\circ}$ direction change within the first $30 \mathrm{~km}$ off northern California. In such complex wind fields the satellite's 25-km space average will interject smoothing errors. If this spatial averaging is the primary source of the larger nearshore errors, then a higher-spatial-resolution technique will reduce this problem but may increase other errors.

Gridded data are designed to depict large-scale meteorological features, not for the point-to-point comparisons we did. The two JPL gridded products we tested suffered for two reasons. First, aliasing is introduced by the satellite's 12 -h sampling rate and its constantly migrating track. Second, the observations include large wind direction errors due to light winds. Consequently, we expected satellite-buoy differences to be larger in the gridded datasets than in the swath data.

Nevertheless, all three datasets would benefit from certain improvements. More precise methods for ambiguity removal and better rain flagging would increase satellite wind accuracy everywhere. Also, increased spatial resolution would improve nearshore accuracy. And, finally, the increased sampling provided by a second satellite scatterometer would improve swath coverage and reduce aliasing in the gridded datasets.

Even with the present QuikSCAT system, however, we found the agreement between such vastly different wind-observing systems as satellites and buoys to be remarkable. Our overall estimate of nearshore satellitebuoy rms differences in swath data $\left(1.3 \mathrm{~m} \mathrm{~s}^{-1}\right.$ and $\left.26^{\circ}\right)$ was within the satellite's design specifications for wind speed $\left( \pm 2 \mathrm{~m} \mathrm{~s}^{-1}\right)$ and close to the design specification for direction $\left( \pm 20^{\circ}\right)$. Moreover, the above comparisons include the errors occurring in buoy data $\left(1 \mathrm{~m} \mathrm{~s}^{-1}\right.$ and $10^{\circ}$ ) as well as errors from our inexact time and space matches.

The results of this study show that the QuikSCAT Level 2B swath data are accurate enough for our planned use in identifying strong upwelling episodes. These satellite wind data will be particularly useful in the many coastal areas of the world's oceans that currently lack in situ wind measurements. However, the nearshore wind data are only marginally useful in light winds because of the satellite's decreased ability to determine wind direction under those conditions. Finally, we believe that the QuikSCAT Level 2B swath data, with modest postprocessing, are sufficiently accurate for many coastal studies.

Acknowledgments. We would like to thank Dr. Curt Collins (Naval Postgraduate School), Dr. Jeff Paduan (Naval Postgraduate School), Dr. Frank Schwing
(NOAA Pacific Fisheries Laboratory), and Dr. Michael Freilich (Oregon State University) for their guidance during this work. We also thank the three anonymous reviewers for their helpful suggestions. Ms. Lynn deWitt provided vital programming assistance. We also acknowledge the considerable contributions and editing provided by Dr. Robert Pickett (Naval Research Laboratory, retired).

\section{REFERENCES}

Atlas, R., S. C. Bloom, R. N. Hoffman, E. Brin, J. Ardizzone, J. Terry, D. Bungato, and J. C. Jusem, 1999: Geophysical validation of NSCAT winds using atmospheric data and analyses. J. Geophys. Res., 104, 11 405-11 424.

Bakun, A., and C. S. Nelson, 1991: The seasonal cycle of wind-stress curl in subtropical eastern boundary current regions. J. Phys. Oceanogr., 21, 1815-1834.

Beardsley, R. C., C. E. Dorman, C. A. Friehe, L. K. Rosenfeld, and C. D. Winant, 1987: Local atmospheric forcing during the Coastal Ocean Dynamics Experiment 1. A description of the marine boundary layer and atmospheric conditions over a northern $\mathrm{Cal}-$ ifornia upwelling region. J. Geophys. Res., 92, 1467-1488.

Cressman, G., 1959: An operational objective analysis system. Mon. Wea. Rev., 87, 367-374.

Dixon, W. J., and F. J. Massey, 1969: Introduction to Statistical Analysis. McGraw-Hill, 638 pp.

Dorman, C. E., and C. D. Winant, 1995: Buoy observations of the atmosphere along the west coast of the United States, 19811990. J. Geophys. Res., 100, 16 029-16 044.

Ebuchi, N., H. C. Graber, and M. J. Caruso, 2002: Evaluation of wind vectors observed by QuikSCAT/SeaWinds using ocean buoy data. J. Atmos. Oceanic Technol., 19, 2049-2062.

FAO, 1995: Yearbook of Fisheries Statistics: Catches and Landings. Vol. 80. Food and Agriculture Organization of the United Nations, 713 pp.

Freilich, M. H., and R. S. Dunbar, 1999: The accuracy of the NSCAT vector winds: Comparisons with National Data Buoy Center buoys. J. Geophys. Res., 104, 11 231-11 246.

Gilhousen, D. B., 1987: A field evaluation of NDBC moored buoy winds. J. Atmos. Oceanic Technol., 4, 94-104.

Halliwell, G. R., and J. S. Allen, 1987: The large-scale coastal wind field along the west coast of North America, 1981-1982. J. Geophys. Res., 92, 1861-1884.

Hamilton, G. D., 1980: NOAA Data Buoy Office programs. Bull. Amer. Meteor. Soc., 61, 1012-1017.

Huddleston, J. N., and B. W. Stiles, 2000: Multidimensional Histogram (MUDH) rain flag product description, version 2.1. Jet Propulsion Laboratory, Pasadena, CA, 8 pp. [Available online at http://podaac.jpl.nasa.gov/quikscat/qscat_doc.html.]

Huyer, A., and P. M. Kosro, 1987: Mesoscale surveys over the shelf and slope in the upwelling region near Point Arena, California. J. Geophys. Res., 92, 1655-1681.

JPL, 2001: QuikSCAT science data product user's manual, version 2.1. Jet Propulsion Laboratory Publ. D-18053, Pasadena, CA, 86 pp. [Available online at http://podaac.jpl.nasa.gov/quikscat/ qscat_doc.html.]

Koch, S., M. Desjardins, and P. Kocin, 1983: An interactive Barnes objective map analysis scheme for use with satellite and conventional data. J. Climate Appl. Meteor., 22, 1487-1503.

Liu, W. T., and W. Tang, 1996: Equivalent neutral wind. Jet Propulsion Laboratory Publ. 96-17, Pasadena, CA, 16 pp. [Available online at http://airsea-www.jpl.nasa.gov/publications.html.]

_,- , and P. S. Polito, 1998: NASA scatterometer provides global ocean-surface wind fields with more structures than numerical weather prediction. Geophys. Res. Lett., 25, 761-764. _, X. Xie, and P. S. Polito, 2000: Atmospheric manifestation of 
tropical instability wave observed by QuikSCAT and Tropical Rain Measuring Mission. Geophys. Res. Lett., 27, 2545-2548.

Long, D. E., and J. M. Mendel, 1991: Identifiability in wind estimation from wind scatterometer measurements. IEEE Trans. Geosci. Remote Sens., 29, 268-276.

Mears, C. A., D. K. Smith, and F. J. Wentz, 2000: Detecting rain with QuikSCAT. Proc. Int. Geoscience and Remote Sensing Symp., Honolulu, HI, IEEE, 1235-1237.

,-- , and - 2001: Comparison of Special Sensor Microwave Imager and buoy-measured wind speeds from 1987 to 1997. J. Geophys. Res., 106, 11 719-11 729.

NASA, cited 2002: SeaWinds on QuikSCAT. [Available online at http://podaac.jpl.nasa.gov/quikscat.]

NOAA, cited 2002: Ocean surface winds derived from the SeaWinds scatterometer. [Available online at http://manati.wwb.noaa.gov/ quikscat.]

Patoux, J., and R. A. Brown, 2001: A scheme for improving scatterometer surface wind fields. J. Geophys. Res., 106, 23985 23994.

Portabella, M., and A. Stoffelen, 2001: Rain detection and quality control of SeaWinds. J. Atmos. Oceanic Technol., 18, 11711183.

Schlax, M. G., D. B. Chelton, and M. H. Freilich, 2001: Sampling errors in wind fields constructed from single and tandem scatterometer datasets. J. Atmos. Oceanic Technol., 18, 1014-1036.
Shaffer, S. J., R. S. Dunbar, S. V. Hisao, and D. G. Long, 1991: A median-filter-based ambiguity removal algorithm for NSCAT. IEEE Trans. Geosci. Remote Sens., 29, 167-174.

Smith, S. D., 1988: Coefficients for sea surface wind stress, heat flux, and wind profiles as a function of wind speed and temperature. J. Geophys. Res., 93, 15 467-15 472.

Spencer, M. W., C. Wu, and D. G. Long, 2000: Improved resolution back scatter measurements with the SeaWinds pencil-beam scatterometer. IEEE Trans. Geosci. Remote Sens., 38, 89-103.

Stiles, B. W., B. D. Pollard, and R. S. Dunbar, 2002: Direction interval retrieval with thresholded nudging: A method for improving the accuracy of QuikSCAT winds. IEEE Trans. Geosci. Remote Sens., 40, 79-89.

Tang, W., and W. T. Liu, 1996: Objective interpolation of scatterometer winds. Jet Propulsion Laboratory Publ. 96-19, Pasadena, CA, 16 pp. [Available online at http://airsea-www.jpl.nasa.gov/ publications.html.]

Winant, C. D., R. C. Beardsley, and R. E. Davis, 1987: Moored wind, temperature, and current observations made during Coastal Ocean Dynamics experiments 1 and 2 over the northern California continental shelf and upper slope. J. Geophys. Res., 92, $1569-1604$

Xie, S. P., W. T. Liu, Q. Liu, and M. Nonaka, 2001: Far-reaching effects of the Hawaiian Islands on the Pacific ocean-atmosphere system. Science, 292, 2057-2060. 